\title{
Clear, Unclear and Non-media - an Attempt at Conceptualisation
}

\author{
KOME - An International Journal of Pure \\ Communication Inquiry \\ Volume 1 Issue 1 p. 20-30 \\ (C) The Author(s) 2012 \\ Reprints and Permission: \\ kome@komejournal.com \\ Published by the Hungarian Communication \\ Studies Assoiciation
}

\author{
János Tóth ${ }^{\mathrm{a}}$, Csaba Vass ${ }^{\mathrm{b}}$ \\ ${ }^{a}$ Eötvös Loránd University, Department of Social Sciences, Hungary \\ ${ }^{\mathrm{b}}$ Károli Gáspár University of the Reformed Church, Institute of Social Sciences and Communication, Hungary
}

\begin{abstract}
Today, the expression "media" firmly retains a broad language function both in professional and public discourse, the essence of which is a signification of the auditory, visual, audiovisual and digital-electronic "press", including both the tools and agents. The term seems scientific from academic viewpoint and precise in public discourse. However, analogies drawn from some of its connotations, which can serve as a foundation to signify various media organisations, are adequate only for some segments of the semantic field of the term and for the roles of various entities described as "media" in the context of mass communication studies. In this paper we shall make an attempt to clarify whether the general name "media" and the more specific "medium" adequately marks the complex institutional system and its individual members to which it is applied in mass communication studies. To this end, after outlining the semantic scope of the term, we will try to identify differences postulated essential in the structure and operation of the constituents of the institutional structure it marks. These differences, viewed through specific types and cases, can either corroborate its use or can necessitate a refinement or rejection of its application.
\end{abstract}

Keywords: media, producent, vertical integration, content production, influence, transformation, transition

\section{Introduction}

The English "media", as the plural form of "medium", comes from the Latin medius, which in turn has its origin in the Greek mésos $(\mu \varepsilon \dot{\sigma o} \varsigma)$. In the following, we will base the starting point of our investigations of the entity referred to in communication sciences as "medium" and "media" on its first dictionary meaning, designating an entity "which lies in the middle, or between other things; intervening body or quantity" (Webster 1913, p.908. This 
generalised definition is also supported by Weekly 1921, p.914, Klein 1967, p.956, Shipley 1979, p.228, Simpson \& Weiner, 1991 , p.554, Valpy 1828, p.255, Andrews 1851, p.935, Niermeyer 1976, p.667, Donnegan 1831, p.808, Giles 1840, p.416, and Liddel and Scott 1883, p.944). The semantic content of these expressions strongly varies even in a particular language. In its variations, the scope of meaning can be broader or narrower. Particularly in different language versions, loss from or addition to the meaning is also traceable: in texts about mass communication - as it is quite well-known, its earliest versions developed in English-speaking countries in the 1920's - the meanings of the English variant will be relevant, where its meaning retains the "in the middle" and "intervening" sense but lacks the meaning components suggesting "impartiality", "neutrality", and "public" of the Greek and Latin terms (Demeter 2011, pp.110-111). The fact that this is not only linguistically relevant is illustrated on the one hand by the classical case of thinking about a "generalized symbolic media," which plays a central role in human life-opportunities and mediates between, as Habermas would say, "system" and "lifeworld," as well as between their subsystems. On the other hand, this relevance is also shown by the current discourses about the social-public role of the media, its potential in forming identities and attitudes, and its role in obtaining and maintaining power. It is easy to understand what significance the examination of the semantic field of the term "medium" has in this study from communication-theoretic viewpoint if we focus on some preliminary questions which can be constructed based both on what is covered by the English term and what is not. At the same time, it can also be put forward that the examination of these questions and the answers to them will serve as a theoretical framework to the examination of the structural and functional characteristics of media organisations.

\section{Preliminary Questions}

Starting with McLuhan, scientific thinking about the media almost always requires a preliminary resolution whether the fundamental questions of the discipline should refer to the media itself or to the media content that is broadcasted or published. This requirement and the wide-ranging variety of conclusions one can arrive at as possible endpoints of the debates will force us too to make this choice with regard to how we will proceed. Mediation carried out by the media requires a complex activity technologically, structurally, and functionally, which, beyond its contribution to mediation, has the potential to be used to achieve other results as well. As experience suggests, these potentials may get actualised with changes in the zeitgeist and in individual and institutional interests, so we tend to side with the opinion that basic research needs to concentrate primarily on the mediator and only secondarily on the mediated content itself. We should also add that an interest in the latter should always remain relative to how the mediator selects and modifies the content. In order to avoid an arbitrariness of division in selecting the object of our research, by identifying an institution as "medium", we will apply the criteria presented in the introduction: the prerequisite of mediation is the middle position. But before proceeding with this categorisation, we need to answer three questions:

1. What is the status of those institutions which are both sources and mediators of the content they transmit? 
2. At what extent does a process, which can be labelled as "transmission", allow the editing of the transmitted content? How and where can the boundary be drawn between simple transmission and the transmission of an edited content, which retains only a level of similarity to the original?

3. From communication-theoretical perspective, is it reasonable not to make a clear distinction between the following types of institutions by naming them uniformly as media?

a. They transmit their own content to their target audience.

b. They modify the content they received from external sources and then transmit the result to their target audience.

c. They simply transmit the unchanged content they receive from external sources.

\section{Discussion}

A short answer to the first question is that the source of message in a process of transmission is not the medium but an agent of transmission. Here, it is appropriate to outline the difference between "mediation" and "disclosure", which is an elemental distinction to make in this writing in order to emphasize either a mediated content or an agent responsible for initiating the process. While the role of the medium is to serve as the vehicle of the mediated content, the agent stands in the role of a producer: the agent produces the disclosed content. This distinction will also point at the middle position of the medium and the terminal position of the producer in the tritransitive process of transmission. If, according to the designated meaning of "medium", we regard the "position between two" as an important criterion, we can supplement the question in the following way: What is the status of those entities, the position of which is between a source and its target (audience) in the mediation process? This wording makes it immediately apparent that the following conclusion can be drawn without any further analysis of the medium, which looks obvious from communication-theoretical perspective but has received little attention so far: the medium as an in-between can be identical neither with the source of the message, nor with its target audience. Furthermore, we can regard no institution or organisation as medium, if it transmits a content produced by itself, instead of one originating in an external source.

Nowadays, when there is more and more emphasis on the research of the large-scale market and organisational convergence which can be observed inside the so-called media sector, this condition cannot be neglected because the convergence can easily reach a stage where the result of a series of corporate mergers and acquisitions will be organisations capable of content production and their distribution through their own media-publishing houses, televisions, radios, and cinema networks (McChesney 2005, Bagdikian 2000, p.xvii, Noam 2009, p.104). These phenomena, as the "vertical integration" of the media, were brought into the focus of attention by media economics and regulation, although this process in fact escapes the scope of media studies because here, both analytically and in reality, one of the terminal members gets integrated with the middle member, which leads to the termination of the middle position, bringing about the dissolution of the medium on organisational level.

Naturally, this does not mean that a vertically-integrated "media" enterprise cannot take part in the process of mediation as a sender instead of a medium. In order to be able to continue the examination of the process of mediation in this environment, where mass communication 
studies traditionally concentrates on media institutions whereas these institutions are gradually disappearing, we need to distinguish the technological tools of mediation from the organisations that use these tools to transmit their "media content". After this distinction has been made, we can include the cases when media enterprises transmit content produced by themselves because, in a technological sense, it can be regarded as mediation, where the medium in this tritransitive process is the technological architecture between the media corporation and the viewer, listener, or reader. The media enterprise here stands in a terminal position, which is incompatible with the designated meaning of the term "medium", and because of which the term could not be used legitimately and adequately. If we broaden our perspective and we concentrate on the organisations instead of the content, then a wellfounded claim can be made that there is a well-defined segment of the set of organisations the categorisation of which as media is problematic: the ones belonging to this segment are those whose profile is predominantly or entirely composed of self-produced content. This problematic nature becomes particularly obvious when a programme produced by the media organisation is about the events or happenings of a situation produced, being produced, or planned to be produced by the organisation itself. ${ }^{2}$ If we dispense with the question of where the content was produced or where it can be positioned and what it makes available, and we concentrate only on the fact that a news item was communicated from point $\mathrm{A}$ to point $\mathrm{B}$, or was made accessible in point $\mathrm{B}$, then we will not be able to make a distinction between a "sender" and a "mediator", or between "disclosure" and "mediation".

Nevertheless, such cases are also possible, where the media enterprise behaves both as a source and a mediator, that is, certain parts of the content are self-produced and other parts mediated. Strictly speaking, even the following assertion can be accepted as true: institutions and organisations in median position cannot function purely as mediators. There is little probability for the realisation of pure mediation, which therefore needs to be handled as an ideal type, that is, as an analytical construct, having its reality as a point of reference, serving the researcher to ascertain similarities as well as deviations in specific cases. One of the first thematizations of this problem was in Habermas's examination of the press organizations of classical civil public sphere (Bürgerliche Öffentlichkeit). The description he published in his seminal work 'The Structural Transformation of the Public Sphere' about the press organisations at the end of the 18th and the beginning of the 19th century is quite close to the ideal type of purely mediating media organisation. For these organisations, both news agencies and professional journalism as a full-time job were unknown, and for the content to be mediated only one editor was employed, who, in some cases, also functioned as an owner, author, and reader; but the role of this person was typically limited to the topical arrangement of the ideas and writings of private citizens making use of their reason, and, if needed, the separation of information from commentary. This led to a situation where, apart from the (civic) interests of the financier, which limited what problems could and could not be discussed, and the norms of public discourse, the reasoning citizens could discuss the problems they regarded as worth discussion based on their experience and not according to the rules of a media organisation. Due to this, the press, at least for a short period of time, "remained an institution of the public itself, effective in the manner of a mediator and intensifier of public discussion" (Habermas 1993, p.183).

The two main characteristics of the press organisations described by Habermas, the facilitation of a public conversation among citizens and a commitment of the organisation to disseminate unbiased and independent information, are properties that helped these organisations not only to meet the technical role of the mediator but also to satisfy the criteria of objectivity and neutrality. For this reason, they can also be regarded as significant contributors to the development of the freedom of speech and expression. 
However, since the publication of Habermas's work, several historical researches (for a summary of which see for example Curran 1991, pp.38-41, and Iosifidis 2011, pp. 31-33) to revise and reveal the facts have provided severe criticisms of his conclusions, which can also serve as an effective refutation of his analysis, for which reason, the reality of a medium behaving purely as a mediator on organisational level cannot be considered as corroborated. It is not the purpose of this chapter, however, to clarify the question whether there existed, exists, or will ever exist an organisation which functions purely and exclusively as mediator of contents produced by others. Instead, our aim is to provide some clues to the creation of a theoretical model making it possible to compare the results of empiria to an ideal situation, and by so doing, media organisations will be comparable not only against each other, in a closed circle, but against a consensually acceptable mode of operation. This objective is not purely theoretical - even though this would be perfectly acceptable in the case of media, as with any targets of basic research-, its significance cannot be neglected from a practical viewpoint either, as it renders comprehensible the various modes of practical application, and at the same time can serve as a propaedeutic of this comprehension.

Pragmatic arguments can also be raised against the practicability of a pure mediating role. In the tritransitive processes, in which the mediation can happen, the mere existence of the medium can make an influence: a given medium is what it is, therefore, not something different, by which it determines the context of transition. ${ }^{3}$ This is true for media with or without an organisation. In media enterprises, another productive effect is also in play: while transmitting, the members of the organisation, who map (or transform) the object of transmission, as a media organisation, recreate the object of transmission in a scene provided by the technological architecture of the medium. As Stuart Hall writes about television broadcasts, which can be extended to include the audiovisual and digital-electronic press as well:

„The 'message form' is the necessary 'form of appearance' of the event in its passage from source to receiver”, and ,a raw historical event can not, in that form, be transmitted by, say, a television newscast. Events can only be signified within the aural-visual forms of the televisual discourse" (1980, quoted by Moores 2005, p.110)

Why the act of transformation or mapping is the product of the media enterprise, and not of any other participant of the mass communication framework, becomes clear as soon as we name the processes which - from the viewpoint of the terminal members of the transmission process - are exactly the opposite of mediation. One of these processes is self-disclosure, when it is the agent who represents oneself, ${ }^{4}$ the one who creates one's own media imprint and selects or creates a medium one deems suitable. In another such process, the initiative is not from the media organisation either but from the media consumer, which is called prosuming, ${ }^{5}$ when the media consumer maps various types of content and makes it available - mainly but not exclusively in internet environment, and inside the framework of participant journalism - through a medium to other consumers.

For this reason, we have to make a distinction for media enterprises having their own organisations whether the content mediated by them is influenced by them or by an external agent, and, in the former case, whether that influence is necessary or unnecessary. The necessary influence on the mediated content exercised unintentionally by mediating organisations, which are nowadays collectively referred to as media, from now on will be called passive influence, which needs to be distinguished from intentional or voluntaristic, that is unnecessary, influences coming from inside the organisations. These influences can be 
summed up in the category of "influencing", which can appear in several stages - namely, thematization, problematization, and formalisation - of the transformation process, where the stages do not necessarily follow each other in the same order or are the consequences of each other.

Thematization is when the media organisation-normally, in accordance with the interests or intentions of the owner or owners - applies a predetermined profile, that is, a preliminary, reference-based selection is made to determine what the owners allow to appear on the interface they provide. As it is quite probable that the medium, because of its own nature, cannot mediate content referring to certain objects, only those cases belong to the sphere of thematization where the exclusion or propagation of a certain content is subject to the voluntarist decision of the organisation. These voluntarist decisions can be further divided into those resulting from the internal regulation of the media company and those originating in conformity to external regulations - typically, state or international law-, nevertheless, in both cases the existence of thematization is a fact. Historical examples ${ }^{6}$ can be listed, as well as contemporary ones, ${ }^{7}$ to support the claim. However, it is more common nowadays that its application is linked to problematization and formalisation in current media environments.

Problematization is the phenomenon where those attributes of the mediated content are edited with which the content in question refers. ${ }^{8}$ This activity can only be fully described as a selection from among the possible interpretations of the original content if editing the attributes presented during mediation does not make the original object or event, which it aims to map, inaccessible. If the meaning is tampered with, references to the original target can be obscured, that is, such a selection of the attributes of the mediated content can be made - by addition, omission, and substitution - that the modified attributes do not refer to the original event or object the mediation of which the content purports to be. This can happen in a way that the mediated content becomes the representation of another original event or object ( $\rightarrow$ misrepresentation), but also in a way that it represents no original event or object ( $\rightarrow$ false representation a.k.a untruth or lie). In problematization, therefore, "editing" signifies a decision-making process the result of which determines what meaning the mediated content can have when it is made public, which enables the organisation of the medium to behave both as a mediator and as a producent, that is, they can manufacture a meaning to the mediated content, while leaving its reference untouched.

Nevertheless, the mediated content can be influenced not only by editing the referring attributes: there is a difference between what meaning the given content has when mediated and what meaning is attributed in the head of the target audience to the mediated content, that is, it is often a part of mediation to edit the perceptibility of the referring attributes of the source. Earlier, it was already mentioned that it is necessary to transform or map the mediated content in the media. However, formalisation techniques used during this transformation process can be used with or without an intent to influence. Those elements of technical editing which are not exclusively for the preservation or improvement of the clarity of the mediated content (e.g. improving image or soundtrack clarity or proofreading the script or article) are especially suitable for this purpose. What concepts and opinions are forming in the heads of the target audience is greatly influenced by the perspective of perception offered by the medium. The perspective of the camera is a good analogy for the perspective of the target audience relative to the content (Rutherford 2002, Jamieson \& Campbell 2006, p.85); camera viewing angle and camera movements in general imitates human space recognition and proxemics (Bordwell 1977) while cuts, transitions and focus can frame mental activities in charge for information processing.

We can firmly state about the relationship between "influence" and "medium" that the former 
is not among the lexical meanings of the latter, but it is also true that it is not a criterion that a medium must be free from any intention to influence. It is a criterion, however, that a medium is in a middle position between the mediated source and the target audience, and it also makes a significant functional difference between different media whether they actively influence the mediated content or not. On the other hand, the current professional and colloquial usage of the terms "medium" and "media" lacks proper distinction and is often inconsistent when used for transmission organisations. Apparently, the basis of the appellation here is the technical-technological capability of the institutions to transmit, which is a common characteristic that we can call, borrowing the mathematical term, "a greatest common divisor".

The most obvious weakness of this appellation is the overgeneralization of the term "media" to an extent of becoming meaningless. It is hard to imagine any entity which is incapable or unsuitable to transmit any received impulse at least on technical level and at least in a fragmentary way. We are in the situation that if we take into consideration the scientific requirement of conceptual clarity - the essence of which is not to use the same name for different phenomena, and even if we do not have a strict definition, it should be possible to give a meaningful explanation about the phenomena being examined - we consider it expedient to make a distinction between institutions commonly called "media" according to whether the content is intentionally influenced and where the content they transmit is created. The following options exist for this distinction:

- we can carry out an examination inside the set of organisations technically and technologically capable of transmittance whether they have any other qualities with class-creating power which are in conflict with the distinctive features of a "medium"

- we can create additional labelled subclasses according to their identifying characteristics inside the class-designating horizon of the "medium"

The first approach provides an opportunity to divide media enterprises on an organisational level into media and producents. Accordingly, the category "producent" will include organisations whose main profile is not mediation but primarily the disclosure of selfproduced content through a given architecture as medium to a given target audience. This approach, not from the previously discussed functionalist viewpoint but with focus on economic (Vass 1992; 2011) and power theoretical issues (Vass 2005; 2010) had already been elaborated by one of the authors of the present article. On the other hand, those organisations can be categorised as "medium" which primarily organise the mediation of content originating outside of them, and this mediation on institutional level is through the media organisation, and on technological level, through the technological architecture they employ.

The second approach also provides an opportunity to make a difference between clear and unclear media from the perspective of content influencing. We call clear media those organisations, where the dominant part of the mediated content is not influenced intentionally, and unclear media are those where a dominant part of the mediated content is under any nonpassive, intentional influence from inside the media organisation.

Furthermore, we cannot rule out the possibility that a given organisation - no matter whether it is a clear or unclear medium, or a producent - shows symptoms of abnormal operation for an insignificant proportion of the transmitted content or programmes, and for this insignificant proportion, it will behave abnormally, showing characteristics of content management that can also be observed in the other two organization types. 
Based on the above, we can assert that institutions capable of technological transmission can be typologized according to their effect on the transmitted content:

\begin{tabular}{|c|c|c|c|}
\hline & $\begin{array}{c}\text { Effects on } \\
\text { content }\end{array}$ & Operation & Type of transition \\
\hline \multirow{3}{*}{ Clear medium } & \multirow{3}{*}{ mediation } & Regular operation $_{\mathrm{cm}}$ & $\bigcirc \rightarrow O \rightarrow O$ \\
\hline & & Irregular operation $_{\mathrm{um}}$ & \\
\hline & & Irregular operation $_{p}$ & \\
\hline \multirow{3}{*}{$\begin{array}{l}\text { Unclear } \\
\text { medium }\end{array}$} & \multirow{3}{*}{ influencing } & Regular operation $_{\mathrm{um}}$ & \\
\hline & & Irregular operation $_{\mathrm{cm}}$ & $\mathrm{O} \rightarrow \mathrm{O}$ \\
\hline & & Irregular operation $_{p}$ & \\
\hline \multirow{3}{*}{ Producent } & \multirow{3}{*}{ producing } & Regular operation $_{\mathrm{p}}$ & \\
\hline & & Irregular operation $_{\mathrm{cm}}$ & $\bigcirc \rightarrow O \rightarrow O$ \\
\hline & & Irregular operation $_{\mathrm{um}}$ & \\
\hline
\end{tabular}

Table 1. General types of effects on transmitted content

\section{Conclusion}

In the discussion above, we made an attempt to present and explain the current problems related to the usage of the word "medium". At the same time, by introducing the term "producent", and through the distinction made between "clear" and "unclear" media, we also tried to make a suggestion for a resolution. The results can confirm us in our conviction that a correct naming of the institutions capable of the transmission in the technological sense has a great significance inside the scientific field and can have great relevance outside the field as well. One of the points we need to emphasise is the application of adequate and precise concepts, which is attached to distinguishing truth from falsehood in the scientific field, establishing and maintaining, though often indirectly, another one of the key points: the scientific reputation of researchers. Finally, this brings forth the rising social-causal stakes of orienting human lives with the help of those with high scientific reputation.

\section{NOTES}

1. In Parsons' AGIL-schema, the generalised symbolic media, that is, money, political power, influence, and value-commitments (Parsons 1975, p.104) serve as generalised interpreter languages to keep contact between the subsystems isolated analytically. This was reconsidered and developed upon from the viewpoint of communication-science by Luhman, distinguishing between language, distributive media, and symbolically generalised communication media (1995, pp.160-161), and by Habermas, differentiating steering media 
replacing language as an action- coordinating mechanism (Parsons A \& G's media) from communication media, preserving its dependence on language and the lifeworld (Habermas 1987, pp.273-282 esp. p.277).

2. A news programme produced internally by a media organisation makes an external event accessible more or less adequately. However, events made available to the target audience via the airing of a self-produced reality show, chat show, drama series etc. have their sources inside the media organisation and can be regarded as the direct construct of the organisation.

3. Naturally, the presence of a medium specifies not only the context of transition but also the wider macroenvironment into which it is integrated. For this reason, a situation can also arise where a medium is introduced into a macro-environment for the very effects of its presence. However, these cases go beyond the scope of this writing.

4. There is only so much overlap between self-representation and the disclosure categories contrasted earlier with mediation, as self-representation, which can be considered a special case of disclosure, is self-disclosure.

5. The same way as McLuhan and Nevit have earlier predicted (1972, p.4), there's a convergence not only between source and medium, but one can also develop between the source and the target audience. Its early conceptualisation on the field of economic theory (Toffler 1980, Kotler 1986) pointed out that prosumption, which unifies the producer and the consumer when production serves one's own consumption, poses a serious challenge in the postindustrial era for the market which traditionally mediates between the product and its consumer, and marketing activities bent on influencing consumer attitudes. For our topic, the significance of this convergence lies in the fact that the prosumer employs a high degree of decoupling between the transformation or mapping process and the media organisation, and thus it also filters out from the process of mediation the content producing and content influencing effects of this organisation.

6. A well-known example is the one in 1956, when the three biggest radio networks of those times (ABC, CBS, and NBC) banned Dot and Diamond's song "Transfusion" on the ground that there is "nothing funny in blood transfusion", and Bob Dylan's "Love for Sale" shared the same fate for its references to prostitution (Gross, Perebinossoff \& Gross 2005, p.201).

7. Iran serves good examples for reference-based selection, where haraam contents or contents leading to haraam are censored or sanctioned on a religious basis, as well as, following a political logic, any references to the holocaust as a historical event (Hejazi 2011, p.57-58). For the same reason, any reference to Tiananmen Square massacre is closely monitored and censored in China (Reporters Without Borders 2009).

8. Strictly speaking, naturally, it is not the content that refers but the perceiver of the content.

\section{Bibliography}

Andrews, E.A., 1851. Copious and Critical Latin-English Lexicon. New York: Harper \& Brothers.

Bagdikian, B.H., 2000. The Media Monopoly. 6th ed. Boston: Beacon Press.

Bordwell, D., 1977. Camera Movement and Cinematic Space. Ciné-Tracks - A Journal of Film, Communications, Culture and Politics, Vol. I. (2), pp.19-27.

Curran, J., 1991. Rethinking the Media as a Public Sphere. In: P. Dahlgren and C. Sparks, eds. Communication and Citizenship. London: Routledge.

Demeter, M., 2011. Médiaszerepek - Adalékok a média kifejezés szemantikájához [Media roles - Increments to the semantics of the term media] In Martin J. - Széchenyi Á. eds. Tanulmányok a 70 éves Buzinkay Géza tiszteletére. Budapest: Corvina Kiadó, pp.110-120.

Donnegan, J., 1831. A New Greek and English Lexicon. 2nd. ed. London: Printed for J.F. Dove.

Giles, J.A., 1840. A lexicon of the Greek language. London: Printed for Longman, Orme, Brown, Green, and Longmans.

Habermas, J., 1987. The Theory of Communicative Action Vol. 2. Boston: Beacon Press.

Habermas, J., 1993. The Structural Transformation of the Public Sphere. Cambridge: The MIT Press. 
Hejazi, A., 2011. 'You don't deserve to be published': Book censorship in Iran. LOGOS - Journal of the World Publishing Community Vol. 22 (1), pp.53-63.

Iosifidis, P., 2011. Global Media and Communication Policy. Basingstoke and New York: Palgrave Macmillan. Jamieson, K.H. and Campbell, K.K., 2006. The interplay of influence: news, advertising, politics, and the Internet. Belmont: Wadsworth Publishing.

Klein, E., 1967. A Comprehensive Etymological Dictionary of the English Language. Vol.2., New York: Elsevier Publishing Company.

Kotler, P., 1986. The prosumer movement: A new challenge for marketers. Advances in Consumer Research, Vol. 13, pp.510-513.

Liddel, H.G. and Scott, R., 1883. A Greek-English Lexicon. 7th. ed. New York: Harper \& Brothers.

Luhmann, N., 1995. Social Systems. Stanford: Stanford University Press.

McChesney, R.W., 2005. The New Global Media. In: E.P.Bucy, ed. Living in the Information Age: A New Media Reader. Belmont: Wadsworth Thompson.

McLuhan, M. and Nevitt, B., 1972. Take today: the executive as dropout. New York: Harcourt Brace.

Moores, S., 2005. Media/Theory: Thinking About Media and Communications. London: Routledge.

Niermeyer, J.F., 1976. Mediae Latinitatis Lexicon Minus. Leiden: Brill.

Noam, E.M., 2009. Media Ownership and Concentration in America. New York: Oxford University Press.

Parsons, T., 1975. Social Structure and the Symbolic Media of Interchange. In: P. Blau, ed. Approaches to the Study of Social Structure. New York: The Free Press, pp.94-120.

Perebinossoff, P., Gross, B. and Gross, L.S., 2005. Programming for TV, Radio, and the Internet: Strategy, Development, and Evaluation. Boston: Focal Press.

Reporters Without Borders, 2009. All references to Tiananmen Square massacre

closely censored for 20 years. Paris: Reporters Without Borders. Available at: <http://en.rsf.org/china-allreferences-to-tiananmen-square-02-06-2009,33198.html> [Accessed 2012-06-10].

Rutherford, A., 2002. Cinema and Embodied Affect. Senses of Cinema, 25. Available at: <http://www.sensesof cinema.com/2003/25/embodied_affect> [Accessed 2012-06-12].

Shipley, J.T., 1979. Dictionary of Word Origins. Totowa: Littlefield, Adams \& CO.

Simpson, J. and Weiner, M., 1991. The Oxford English Dictionary. Vol.IX. 2nd. ed. Oxford: Clarendon Press.

Toffler, A., 1980. The Third Wave. New York: Bantam Books.

Valpy, F.E.J., 1828. Etymological Dictionary of the Latin Language. London: A.J. Valpy.

Vass, Cs., 1992. A Média a Rendszerváltásban. [The Media in the Political System Change.] s.l: .Magyar Országgyülés Kulturális Bizottsága.

Vass, Cs., 2005. A Nyilvános Identitástermelés Társadalomgazdasági Problémáiról a Közszolgálati és a Kereskedelmi Televíziók Kapcsán. [On the Problems of the Public Production of Identities in Connection with Public and Commercial Televisions] In Vass Cs. ed., 2005. Hatalom, Szakralitás, Kommunikáció. Budapest: Kölcsey Intézet., pp. 100-119.

Vass, Cs., 2010. A médiától a producensig. A média és a producens hatalomelmélete. [From Media to Producent. The Power Theory of Media and the Producent] Budapest: Alkalmazott Kommunikációtudományi Intézet. 
Vass, Cs., 2011. A média és producens gazdaságelmélete. [The Economic Theory of Media and the Producent] Budapest: Alkalmazott Kommunikációtudományi Intézet.

Webster's Revised Unabridged Dictionary, 1913. G \& C. Merriam Co. Available at: $<$ http://machaut.uchicago.edu/websters $>$ [Accessed 2012-06-03].

Weekly, E., 1921. An Etymological Dictionary of Modern English. London: John Murray.

\section{Author Contributions}

Created and developed (in previous works) the original idea on which the concept of the manuscript is based: Cs.V. Developed the concept and drafted the manuscript: J.T. Reviewed and critically commented the draft version: Cs. V. Revised the draft, prepared the tables and wrote the manuscript: J.T. All authors take full responsibility for the content of the paper. 